\title{
A Study on Trial Implementation of Information Sharing Site about Copyright Processing by University Cooperation
}

\author{
Akie YOSHIDA, Hiroshi MURAI and Toshihiro KITA
}

\begin{abstract}
In this research, the aim is to improve the efficiency of copyright processing of e-Learning teaching materials shared across teachers and universities. In Japan, an amendment of the copyright law is to be implemented in January 2019, therefore, changes are expected to be made by educational institutions accordingly. By clarifying the changes and the measures (tasks) taken to adapt to the changes now, copyright will be capable of being processed in a more flexible manner.
\end{abstract}

Keywords - e-learning, Copyright processing, university collaboration, e-learning, information sharing

\section{INTRODUCTION}

There are many university cooperative e-Learning projects with the credit transfer system. Credit transfer system is a learner-centered system based on the flexibility of course selection among the cooperated universities. But the registration procedure is a difficult problem for increasing the number of students.

The other hand, the University Consortium for e-Learning, Shikoku Center, which is an organization of university cooperative e-learning in Shikoku Area, does not adopt the credit transfer system for convenience of the course registration procedure. There are five national universities, namely, Kagawa University, Ehime University, Kochi University, Naruto University of Education and Tokushima University, which have been conducting collaborative projects since 2013 shown in Fig. 1.

\begin{tabular}{|c|c|c|c|}
\hline \multicolumn{4}{|c|}{$\begin{array}{c}\text { University Consortium for e-Learning, Shikoku Center } \\
\text { Kagawa university }\end{array}$} \\
\hline $\begin{array}{c}\text { Branch office } \\
\text { Ehime } \\
\text { university }\end{array}$ & $\begin{array}{c}\text { Branch office } \\
\text { Kochi } \\
\text { university }\end{array}$ & $\begin{array}{l}\text { Branch office } \\
\text { Tokushima } \\
\text { university }\end{array}$ & $\begin{array}{l}\text { Branch office } \\
\text { Naruto } \\
\text { University of } \\
\text { Education }\end{array}$ \\
\hline
\end{tabular}

Fig. 1. Organization of collaborative project.

Fig. 2 illustrates that the universities produce unique e-Learning contents mutually to open elective subjects in their own course. Some series of e-learning courses are opened as their own courses in each university, therefore, the students can register the course by a procedure same as other courses in their university. The students can select the courses without consideration which university opens the course.

Akie YOSHIDA is with the Ehime University, Ehime, 790-8577 Japan. Hiroshi MURAI is with the Yamaguchi University, Yamaguchi, 753-8541 Japan.

Toshihiro KITA is with the Kumamoto University, Kumamoto, 860-8555 Japan.
Fig. 2. Series of e-learning courses are opened as their own courses in each university

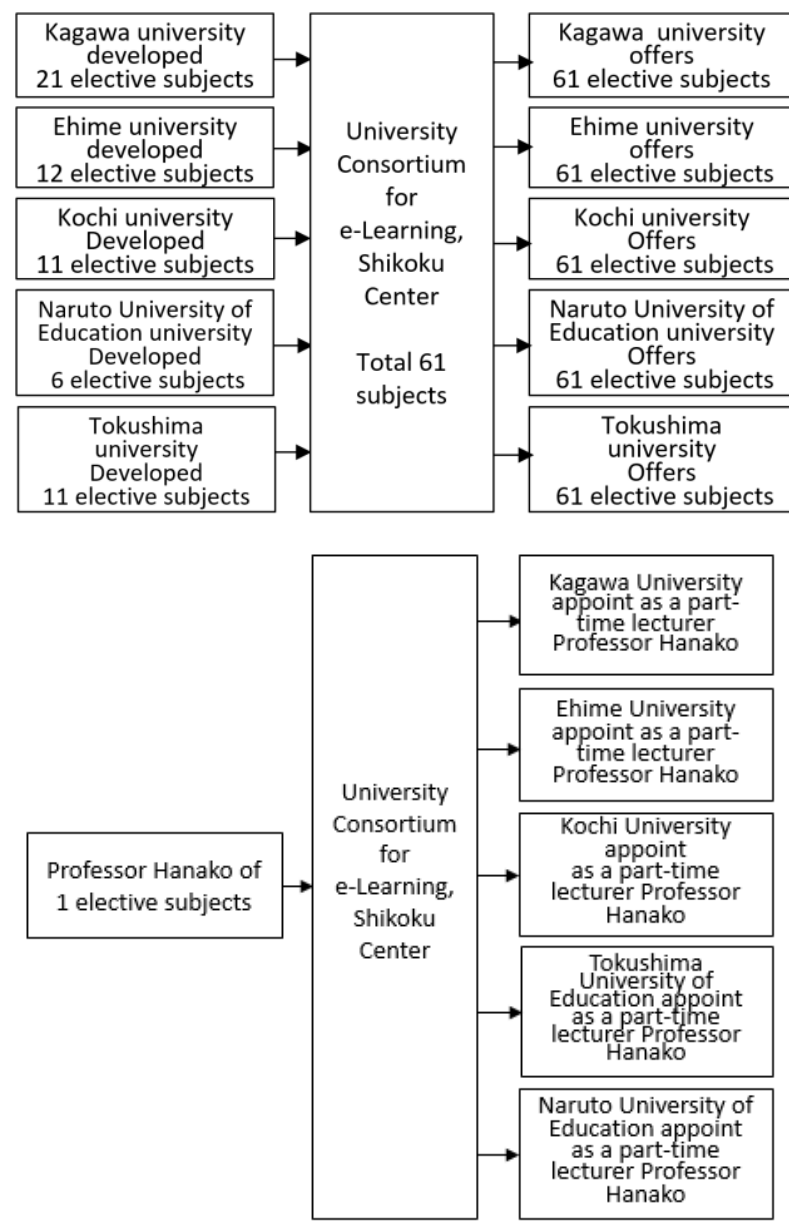

Fig. 3. Appointment of part-time lecturer.

Fig. 3 shows that the teacher of the elective subject is employed as a part-time lecturer at the all university.

\section{COPYRIGHT MANAGEMENT AT THE FIVE NATIONAL UNIVERSITIES IN SHIKOKU}

When using the copyrighted work of a third party in e-learning, permission from the copyright owner must be obtained in principle. However, it is impractical to introduce unified copyright processing at all universities because the processing is different from each university. We decide on three steps of policy regarding copyright processing as shown in Fig. 4. 
STEP1 The copyright processing at the production stage was left to the policy of each university. (At Ehime University, staff members are handling copyright processing on behalf of course teachers.)

STEP2 The copyright processing at the Usage and management stage was left to the policy of each university. (Ehime University transfers copyright from Course teacher to university.)

STEP3 Our project stipulated mutual use in guidelines.

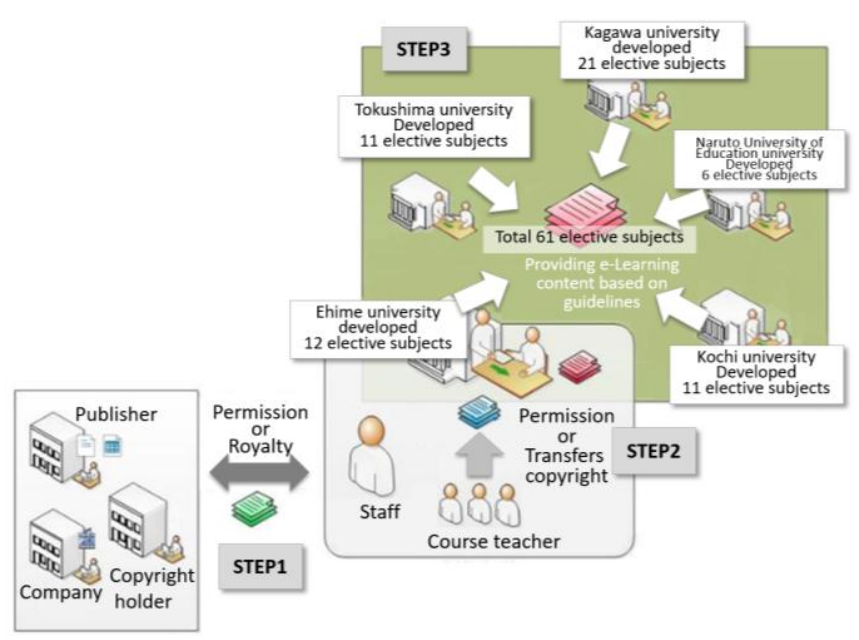

Fig. 4. Three stages in copyright processing.

Thus, the copyright processing at the production stage was left to the policy of each university.

\section{COPYRIGHT HANDLING IN EHIME UNIVERSITY}

As the number of e-learning students is very large, in order to prevent copyright infringement, it was decided by the Ehime University group to deal with copyright application for all materials of all third parties. Figure 5 shows the flow of final copyright processing at Ehime University.

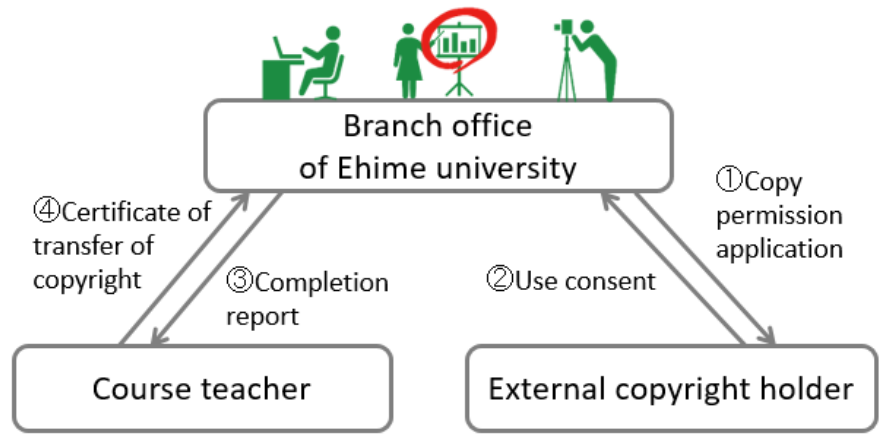

Fig. 5. Flow of copyright processing at Ehime University.

When Ehime University first began producing e-Learning content, the two officials in charge of production had neither knowledge of the copyright law nor experience of copyright processing. From the very beginning, improvement was made by trial-and-error .
In terms of e-contents used during classes at Japanese educational institutions, third-party works can be freely used under certain conditions as an exception to the copyright law. As a result, when re-using teaching materials (used in lessons with e-Learning contents), the source is unknown. The search for the copyright holder can be very problematic. Even in cases where copyright holders are found, as there is often no budget, copyright holders request for royalties resulted in the using of replacement materials and images. Fig. 6 shows that up until this point, we have applied for copyright permission to over 10 countries, and processed various copyrights.
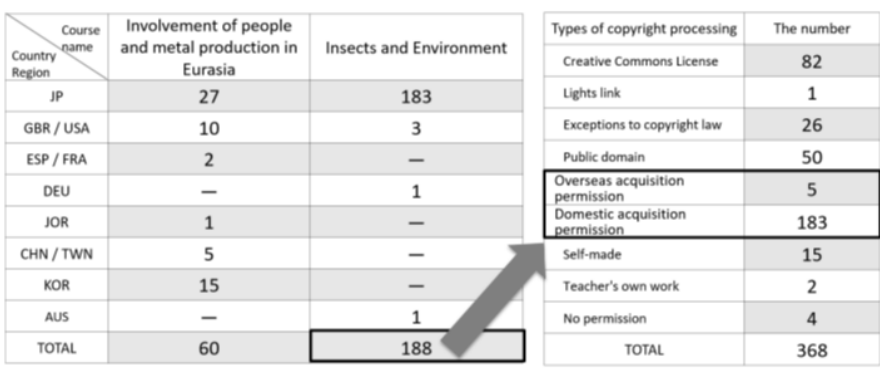

Fig. 6. Number of permissions received from copyright holders.

It was also necessary to judge the need for unnecessary copying permission application, and at the beginning of the commencement, a professional consultant was needed. In the middle of the copyright processing work, a professor Murai, who was familiar with copyrighting (at Kagawa University), was found and gave consultation on SNS.

Through this experience so far, it has been assumed that sharing knowledge and experience would lead to more efficient copyright processing amongst our five universities Consortium for e-Learning, Shikoku Center.

\section{INFORMATION SHARING AMONG FIVE UNIVERSITIES}

Fig. 7 shows that as it was assumed that the burden on the other four universities could be reduced, the 'know-how' and issues faced by Ehime University were shared with the 5 universities. (The other four universities are Kagawa University, Kochi University, Tokushima University, and Hokkaido University ) .

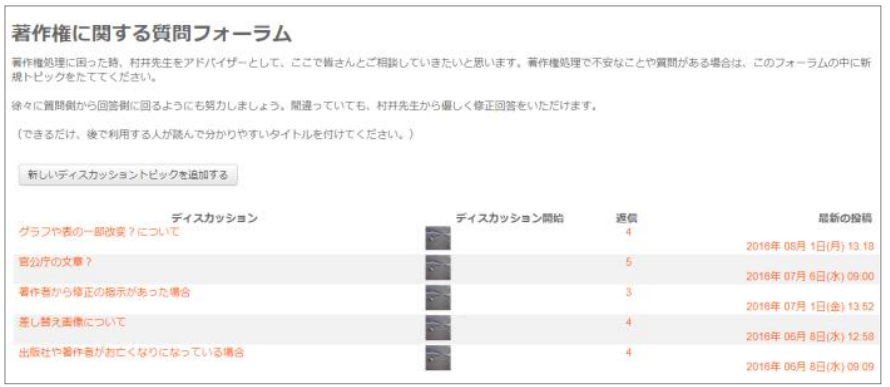

Fig. 7. Information-sharing sites concerning copyright.

For each question written on the SNS bulletin board, a primary answer was provided from practical experience and related information first, and then the professor of Kagawa University responded from a copyright law perspective. 


\section{INFORMATION SHARING AND THE FUTURE FOR COPYRIGHT LAW REVISION}

With the revision of the copyright law from Jan 2019, a new compensation system will be introduced. Each educational organization will be able to freely use the copyrighted material at e-Learning by paying the compensation fee to the designated management organization. However, since the upper limit of the number of users is not clear, there is much ambiguity such as how to handle e-Learning opening in a large number of universities.

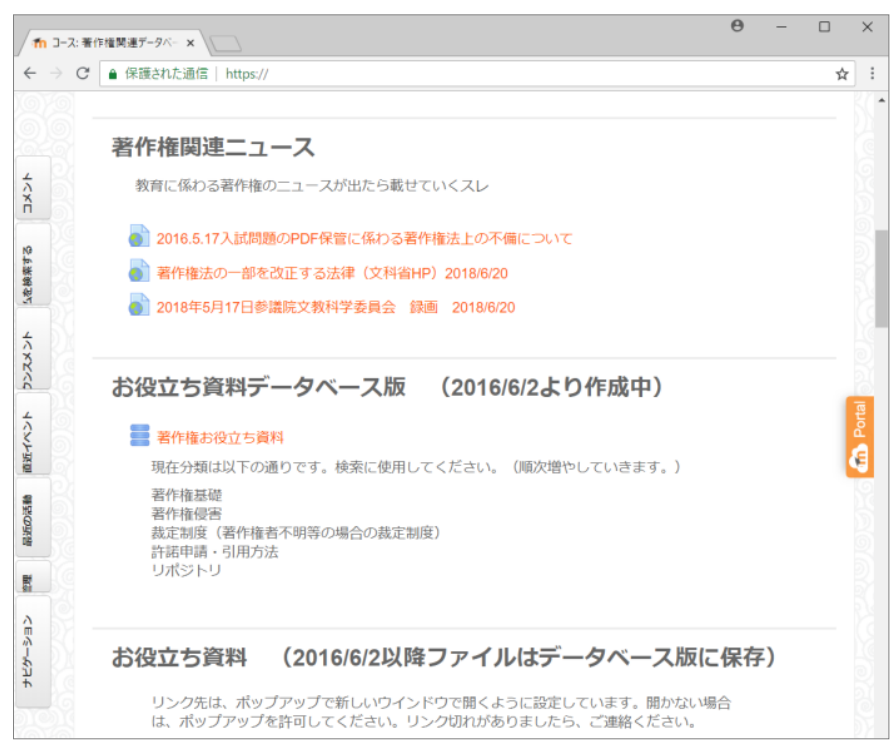

Fig. 7. Information-sharing site among teachers

In order to share these unanswered questions and to consider solutions, the aim of this project is to create a place for sharing information among teachers on SNS, where teachers will be able to communicate with each other to tell how to use e-Learning materials under copyright law.

Currently, faculties interested in copyright processing from Hiroshima University, Yamaguchi University and Jichi Medical University 's teacher have been registering on this SNS, and a place of information sharing will be being designed. Figure 8 is the SNS planned to operate as an information sharing site among teachers. The results of information sharing will be announced in the future.

\section{REFERENCES}

[1] Hiroshi Murai, Toshihiro Hayashi, Rihito Yaegashi, Kazuhiro Ura, Keizo Saisho, Yoshiro Imai, Norifumi Suehiro, "A Study of Load-Balancing Strategy Based on Students' Action on University Cooperative e-Learning", Proceedings of 16th IEEE/ACIS International Conference on Software Engineering, Artificial Intelligence, Networking and Parallel/Distributed Computing (SNPD 2015), pp.587-590, June 2015. https://doi.org/10.1109/SNPD.2015.7176265

[2] A. Yoshida, K. Jinnai, J. Nemoto, T. Tanaka, K. Fujimoto, H. Murai, and T. Hayashi, "Construction of Basic Cases to Systematize Copyright-Processing for e-Learning," IPSJ SIG Technical Report, vol. 2017-CLE-21 No.12, pp. 1-4, March 2017. [published in Japanese]

[3] A. Yoshida, J. Nemoto, T. Tanaka, H. Murai, and T. Hayashi, "A Study of Copyright-Processing Support for University Cooperative e-Learning", JSiSE2016, D4-3 pp. 305-306, August 2016. [published in Japanese]
[4] A. Yoshida, J. Nemoto, T. Tanaka, H. Murai, and T. Hayashi, "A study on e-Learning contents and licensing process third-party copyrighted materials among five national universities in Shikoku area", Research report of JSET Conferences, vol. JSET2016-1, pp. 413-416, March 2016. [published in Japanese]

[5] H. Murai, K. Kanenishi, A. Takahashi, K. Takeguchi, T. Tanaka, J. Nemoto, M. Nakamichi, Y. Miyoshi, and T. Hayashi, "A Proposal of Copyright Processing for Smooth Management of the University Cooperative e-Learning Education at the 5 National Universities in Shikoku Area", JSiSE2015, F4T-3 pp. 297-298, September 2015. [published in Japanese] 